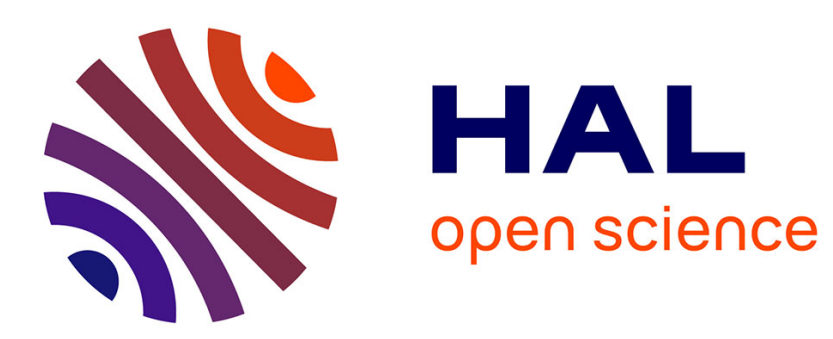

\title{
William S. Burroughs and The Wild Boys Against the Language Virus: A Biosemiotic Guerilla
}

Pierre-Louis Patoine

\section{To cite this version:}

Pierre-Louis Patoine. William S. Burroughs and The Wild Boys Against the Language Virus: A Biosemiotic Guerilla. Revue sémiotique canadienne RS/SI, 2019, 39, pp.19 - 36. 10.7202/1076228ar . hal-02306559

\section{HAL Id: hal-02306559 \\ https://hal.science/hal-02306559}

Submitted on 6 Oct 2019

HAL is a multi-disciplinary open access archive for the deposit and dissemination of scientific research documents, whether they are published or not. The documents may come from teaching and research institutions in France or abroad, or from public or private research centers.
L'archive ouverte pluridisciplinaire HAL, est destinée au dépôt et à la diffusion de documents scientifiques de niveau recherche, publiés ou non, émanant des établissements d'enseignement et de recherche français ou étrangers, des laboratoires publics ou privés. 
Preprint version. Please cite from:

Recherches Sémiotiques Semiotic Inquiries, 2019, vol. 39, n 1-2, p. 19-36.

\section{William S. Burroughs and The Wild Boys Against the Language Virus: A Biosemiotic \\ Guerilla}

Pierre-Louis Patoine

\section{Summary}

This article proposes a biosemiotic reading of William S. Burroughs' The Wild Boys - A Book of the Dead (1971), showing how literature, by cutting up narrative structures and syntactical units, can fight the language virus' configuring of human vitality, just like bacteria uses CRISPR-Cas9 to cut-up the DNA code-chains of threatening viruses. We will see that, supported by the shared biosemiotic nature of literary texts and biological forms, this parallel extends beyond the metaphorical to reinsert literature within the realm of living processes.

Cet article propose une lecture biosémiotique du roman de William S. Burroughs The Wild Boys - A Book of the Dead (1971), montrant comment la littérature, en coupant structures narratives et unités syntaxiques, peut combattre le "virus du langage" et les contraintes qu'il impose à la vitalité humaine. Cette tactique rappelle la manière dont certaines bactéries utilisent le CRISPR-Cas9 pour couper l'ADN de virus attaquants. Nous verrons que, en raison du caractère biosémiotique que partagent les textes littéraires et les formes biologiques, ce parallèle nous permet de réinsérer la littérature au sein des dynamiques du vivant. 
Certainly one of the most brilliant writers of the postwar period, William S. Burroughs' influence on the cultural avant-gardes of the late $20^{\text {th }}$ and early $21^{\text {st }}$ century is pervasive. He has been called the godfather of the Beat poets (Kerouac and Ginsberg were friends), an inspiration for the punk rock movement of the 1970s onward (David Bowie, Lou Reed, Patti Smith, Debbie Harry and Kurt Cobain all had their picture taken with him), and the first of the cyberpunk writers (such as William Gibson, Pat Cadigan, and Bruce Sterling). His influence is often attributed to the power of his subversive imagery and to his use of the cut-up technique, a formal innovation that gives its characteristic style both to Naked Lunch, first published in 1959 and the object of two censorship trials, and to the "Nova Trilogy" formed by the Soft Machine (1961), The Ticket that Exploded (1962), and Nova Express (1964). Following on their heels is The Wild Boys - A Book of the Dead (1971), which uses "cut-uplike" techniques in a slightly toned down manner.

Subversion and experimentation are crucial to Burroughs' oeuvre. But they cannot be separated from its intense connection with the biological, with the experiences of aliveness it gives its readers. Of course, all literature is connected with the biological, as writing and reading are practiced by living entities (individual writers and readers, and their communities and cultures, co-evolving with entities and materials such as paper/trees and ink). Moreover, all literature expresses or creates fragments of vital experience; meaning-making and interpretation are embodied through the reader's neural simulation of sensory and emotional images, with its accompanying postural, muscular and visceral correlates (see work on embodied cognition such as Gallese and Lakoff 2005; or Boulenger et al 2009). These biological and physiological aspects of poetical and narrative practices are widely shared, but the entanglement of Burroughs' writing with the biological, the physiological, the botanical 
and the animal remains extraordinary, immersing the reader in strange ecologies where his sensory-motor, metabolic and reproductive modes of being are reconfigured.

This is especially true of his classical works from the "long 1960s," a period that ends with the publication of The Wild Boys - A Book of the Dead in 1971, and of Port of Saints in 1973. Reaping the fruits of the four experimental novels that precede it, The Wild Boys succeeds in balancing the disruptions of the cut-up with a relatively stable narrative frame combining multiple figurative threads, chronotopes, voices and points of view. The experimental force and subversive seduction of this assemblage are of a biosemiotic nature: it is through its interbreeding of bios and semiosis that its images (iconic legisigns, to use Peirce's typology; see Fisette 1996 about their importance in art and literature) allow us to experience unusual desires and modes of reproduction. In The Wild Boys, the entanglement of Burroughs' writing with the biological is born out of a phenomenology of animal-vegetal-media becomings in which hybrid life-forms oppose the biopower of the language virus and its deadening forces of mind- and body-control, a confrontation that plays out at various scales of the text (syntactical, narrative, imaginary, conceptual). In this, The Wild Boys lengthens the aesthetic and ethical axes that pass through Naked Lunch and The Nova Trilogy, and that are explicit in the 1970 essay The Electronic Revolution.

\section{Approaching The Wild Boys: text and context}

The Wild Boys opens with a "Mexican scene," viewed through the floating eye of a cameravulture, and centered on the fortune-teller/newspaper seller Tia Dolores and her husband Tio Pepe (who casts spells on sleeping or drunk individuals by whispering deadly suggestions in their ear, such as cuerpo carbonizado... cuerpo carbonizado; a demonstration of the 
physiological performativity of language aimed at by Burroughs' writing). Dolores and Pepe are somehow protecting their delicate son Joselito against aggressive pistoleros and neighbors. Joselito is a "little kitten" of Lola, the three-hundred pounds drug seller that feeds her queer protégés with her "great purple dug[s] bitter with heroin" (1971: 11). We won't see these characters again, but the stage is set: queers, drugs, violence, non-normative bodies, folkshamanism, a fantasized Latin-America, and media (especially photography and film) are all crucial dimensions of the surreal universe of The Wild Boys. The seventeen following chapters travel through different spaces and times (with special focus on chronotopes such as Marrakech/Tangier/the Blue Desert 1976/1988, and St Louis Missouri 1920), between which characters, words and images circulate. We explore these interconnected chronotopes through the erotic/exotic/media experiences of characters such as the young men Audrey, Kiki and Johnny, or CIA agents and US Army personnel. The main thread emerges through recurring images and phrases: it is that of the "wild boys," an international (mostly Latin American and African) network of gloriously hybrid shamanic young men ("snake boys in fish-skin jockstraps," Warrior Ants division boys, "glider boys with bows and laser guns, roller-skate boys-blue jockstrap and steel helmets": 147). These boys are preparing to free North America and Western Europe from the "police machine and all its records" and "all dogmatic verbal systems" (139-140). This loose narrative is constituted by a variety of images intermeshed with first- and third-person testimonies: sepia photographs in gilded books (memorabilia from the American 1890s and 1920s), the recurring "penny arcade show" but also military films from the 1970s and 80s. These media presences often lead to ekphrasis (the vivid description, by a text, of an artwork). Indeed, ekphrasis is an organizing principle of The Wild Boys: images become so vivid that they turn into worlds that characters penetrate, just like the reader can enter and inhabit Burroughs' textual worlds. The ekphrastic text - by becoming an 
inhabitable space, a habitat - possess a form of biological agency not unlike the power of Tio Pepe's words to change the embodied destiny of his victims.

It is useful to give right away a feel of the novel's use of these ekphrastic gates and openings. As an example, let us take chapter eight, "The Miracle of the Rose," a title that functions as an homage to Jean Genet's 1946 novel of the same name. The chapter begins as a conventional narrative:

June 23, 1988. Today we got safely through the barrier and entered the Blue Desert of Silence. [...] I have two guides with me Ali a Berber lad with bright blue eyes and yellow hair a wolfish Pan face unreadable as the sky. The other Farja of a dusky rose complexion with long lashes straight black hair gums a bright red color. We are wearing standard costumes for the area: blue silk knee-length shorts, blue silk shirts, Mercury sandals and helmets. (71)

The flashy, vivid colors (blue and bright blue, yellow, dusky rose, bright red) and pop, exotic and surreal imagery (blue silk shorts, a Berber lad, a Pan face and Mercury sandals) make the scene vividly imaginable, an immersive set up in which the reader can project himself, identify with the first-person narrator in his interest for these attractive, fantasized guides. The text describes the character's march through the desert and their arrival to ruins with a "room with rose wallpaper." Ali and Farja will then engage in sex, which will rapidly become oneiric as "nitrous fumes twisted from the pink rectal flesh in whorls of orange and sepia" (73). Human and vegetal will then conflate in an erotic/horrific configuration, making the text jump to another diegetic level:

A scream of roses burst from tumescent lips roses growing in flesh tearing thorns of delight intertwined their quivering bodies crushed them together writhing gasping choking in an agony of roses sharp reek of sperm. 
Sepia picture in an old book with gilt edges. THE MIRACLE OF THE ROSE written in gold letters. I turn the page. A red color that hurts transparent roses growing through flesh the other leans forward drinking roses from his mouth their hearts translucent roses squirming in naked agony [... sentence continues without stop] musty house slow smile you there dim jerky bedroom 18 on the top floor $::$ : my flesh $:::$ I could $:::$ the film breaks : : : jerky silent film [...] : : : sadness in his eyes 1920 movie (p. 73-74) From the first-hand account ("Today we got safely through the barrier") to the "sepia picture in an old book" that becomes in turn a hallucinatory experience and then an old film (sepia, broken), The Wild Boys bounces from one level of reality to another. These jumps, made possible by the intensity of images, colors, textures and scents, are offered to us as mode of reading, tempting us to enter physically Burroughs' text by letting ourselves be conquered by its images, and by embracing our potential for hybridizing and for biological communion with media-animal-vegetal bodies ("I turn the page feeling the rose twist alive in my flesh": 77).

This biosemiotic use of ekphrasis serves Burroughs' project of intensifying vital experience against the constraints of good taste and good sense prevalent in his time. Although we cannot consider this artistic project as a pure product of its historical period, it is still fomented during the American 1950s and 1960s. It resonates with the zeitgeist of these decades obsessed with social and ideological control, marked by McCarthyism and the development of cybernetics, by the Cold War and its fear of brainwashing and mind-control (see Dunne 2013 on this last point). Control is thus central to these decades' imaginary, and it is precisely against this paradigm of control that the counterculture and hippie movement of the 1960s and 1970s will try to free mind and body. Burroughs' writing is related to this movement, and shares its concerns with issues of control and liberation (it is unsurprising that the main element Deleuze (1992) took from him is the very term "control”). But his oeuvre takes a 
unique stand on these issues by linking them with the virus as a non-human force of control operating through language.

At the time Burroughs is writing against the "language virus," the "viral paradigm" that will develop in the 1980s with the parallel emergence of the AIDS epidemic and of computer viruses (Bardini 2006) has yet to emerge. Moreover, in the 1960s, microbiology has not become the game-changing field it will become in the 2010s with the development of environmental microbiology and of studies of the human microbiome. Rather, in the decades when Burroughs composes Naked Lunch, The Nova Trilogy, and The Wild Boys, it is molecular biology that is on the rise. Indeed, in April 1953, Nature publishes the seminal article of Francis Crick and James Watson, and that of Maurice Wilkins and Rosalind Franklin, both of which proposing a basic structure for DNA. Ten years later, in 1962, Crick, Watson and Wilkins (Franklin died in 1958) get the Nobel Prize in Physiology or Medicine "for their discoveries concerning the molecular structure of nucleic acids and its significance for information transfer in living material" (Nobel Foundation). This award fuels the popularization of genetics, during the same period in which Burroughs' theorizes the "language virus." These events resonate with each other, as in both cases, code and control are associated; the genetic and the linguistic codes both appear to drive human destiny, and to supersede human rationality and autonomy (see Hayles 1999 for details on the "rise of code" in the last decades of the $20^{\text {th }}$ century and its impact on conceptions of the human). Of course, genetic and linguistic codes do not obey the same principles. Even though the informal nature of genetics has lead many scientists to compare it with language, for example with algorithmic languages (or cybernetic programs) in the work of geneticists François Jacob, Jacques Monod and André Lwoff (Bardini 2011 : 72), or in that of linguists following the pioneer work of Roman Jakobson (1973), like Bel Enguix and Jiménez-Lopez (2012), this 
comparison cannot be done lightly. Charbel, Queiroz and Emmeche (2009) or Bardini (2011) remind us of the fallacies involved a strict analogy between genetic and linguistic signs. Still, the genome-as-language metaphor is still in use, and might hold some heuristic value. In a short clip for Franco-German TV channel ARTE, microbiologist Emmanuelle Charpentier (2016), head of the Max Planck institute for Infection Biology and official co-developer (with Jennifer Doudna) of the technique using CRISPR-Cas9 to edit human genomes, explains how the later "works kind of like a word processor, with which you can erase words, put new words, and even correct a precise letter." The textual description of CRISPR-Cas9 reveal the existence of parallels between genetic and linguistic processes, parallels we will follow to understand Burroughs' biosemiotic guerilla against the controlling power of code.

\section{Uncovering the language virus}

In his essay The Electronic Revolution, first published in 1970, Burroughs explicitly articulates his theory of the language virus. Although it reads like a scientific or philosophical argument, The Electronic Revolution should be understood as an integral part of Burroughs' artistic oeuvre: its free and energetic style, and its integration of fictional characters (such as Doktor Kurt Unruh von Steinplatz from The Wild Boys, who also appears in Burroughs' interviews in The Job 1979) marks it both as a direct appendage of the novels of this period, and as their interpretive key, a manifesto expressing some of their political and aesthetical underpinnings.

Many ideas from The Electronic Revolution can be traced back to Kozybski's "General Semantics" that explain how our knowledge and experience are limited both by the structure of our nervous system and by that of our language. A somewhat neglected part of the 20th 
century's intellectual history, Korzybski's ideas has influenced directly or indirectly thinkers such Baudrillard, Deleuze and Foucault (Bardini 2014) and writers like Robert Heinlein, A. E. Van Vogt (Konstantinou 2014), and of course Burroughs who, in The Electronic Revolution, discusses Korzybski's (1921) theory of time binding (i.e. through writing, humans can maintain information across time) before postulating that language, and especially the written word, is a virus:

We may forget that a written word IS AN IMAGE and that written words are images in sequence that is to say MOVING PICTURES. So any hieroglyphic sequence gives us an immediate working definition for spoken words. Spoken words are verbal units that refer to this pictorial sequence. And what then is the written word? My basic theory is that the written word was literally a virus that made spoken word possible. The word has not been recognized as a virus because it has achieved a state of stable symbiosis with the host. (2005: 4-5)

Two words are important in this provocative reversal of the traditional ontogeny of language (as here, writing precedes speech). The first one is sequence: the viral agency of the written word is linked with its syntactical arrangement. It is because words form sequences of images, hieroglyphic chains of moving pictures that they are viral agents. The linearity and consecution of written words appear to condition the concepts (images) to which the spoken words refer. The second important word is literally: for Burroughs, the language virus is not a metaphor, but an evolutionary fact, even if it is a hypothetical or even a mythical fact. This evolutionary myth is later elaborated through sensuous, physiological images of the infection that forced apes into humanity:

One reason that apes can't talk is because the structure of their inner throats is simply not designed to formulate words. He [Doktor Kurt Unruh von Steinplatz] postulates that alteration in inner throat structure were occasioned by virus illness... And not occasion... 
This illness may well have had a high rate of mortality but some female apes must have survived to give birth to the wunder kindern. The illness perhaps assumed a more malignant form in the male because of his more developed and rigid muscular structure causing death through strangulation and vertebral fracture. Since the virus in both male and female precipitates sexual frenzy through irritation of sex centers in the brain the males impregnated the females in their death spasms and the altered throat structure was genetically conveyed. (2005: 6)

Through the fictional figure of von Steinplatz, Burroughs calls forth a "deep history" of language rooted in animality, body modification, death and sex. This mythography insists on the biosemiotic linkage of the physiological and the linguistic; a violent and erotic linkage created by a virus able to supersede voluntary behavior and "precipitate sexual frenzy," leading to its own transmission and flourishing.

This primordial infection leads to speciation, as the host forms a symbiotic relationship with the virus, eventually seeing it as "a useful part of itself" (although the pioneer work of Lynn Margulis on the genetic and evolutionary consequences of symbiosis has been around since the 1970 s - see for example Margulis 1976 - speciation by symbiosis has only recently become widely accepted by biologists in the 2000s (for the speciation of eukaryote cells) and the 2010s (for the holobiont as a level on which natural selection operates; for details see Brucker and Bordenstein 2012, Rosenberg 2014, and Bapteste 2017). Burroughs then explores various configurations of the word virus, mainly theological (the Fall from Eden) and media/political (the Watergate scandal), before explaining that once it has accessed the cell, viral infection enters its third and final step, the production of objective reality:

Number 3 is the effect produced in the host by the virus: coughing, fever, inflammation. NUMBER 3 IS OBJECTIVE REALITY PRODUCED BY THE VIRUS IN THE HOST. 
Viruses make themselves real. It's a way viruses have. (2005: 7)

Objective reality is thus produced alongside coughing, fever and inflammation. In Burroughs' symptomatology, these belong to the same biosemiotic order: that of embodied living. In keeping with Korzybski's "General Semantics," this production of reality is specifically made by phrases and media sequences, by syntactical chains associating affects and images, words and behavioral responses. Indeed, for Burroughs: "The control of the mass media depends on laying down lines of association. When the lines are cut the associational connections are broken." (2005: 13) This strategic cutting of lines of association will be instantiated in his use of the cut-up technique, of which we will discuss in a moment. The obvious relation between the cut-up and Burroughs' anti-viral guerilla has been discussed before (for example in Batt 1976 or 1992, or Lydenberg 1987), but we will see here that this formal strategy, with its mythical-biological roots and implications, is close to actual biological dynamics.

In the last section of The Electronic Revolution, Burroughs identifies a number of words that would be responsible for mind control and the viral production of "objective reality":

This IS OF IDENTITY. You are an animal. You are a body. Now whatever you may be you are not an "animal," you are not a "body," because these are verbal labels. The IS of identity always carries the assignment of permanent condition.

THE DEFINITE ARTICLE THE. THE contains the implication of one and only: THE God, THE universe, THE way, THE right, THE wrong [...]. The definite article THE will be deleted and the indefinite article A will take its place. 
THE WHOLE CONCEPT OF EITHER/OR. Right or wrong, physical or mental, true or false, the whole concept of OR will be deleted from the language and replaced by juxtaposition, by AND. (2005: 33-34)

It is not a coincidence that THE and OR are targeted here: an article and a conjunction, they are syntactical words, they create sequences and association lines. Of course, deciding to replace them by A and AND does not suppress the sequentiality or associativity of discourse. But it identifies syntax as a site of power (the power to control thought and the forms taken by human lives). And even though Burroughs does not implement this grammatical utopia in his own text, its sole existence destabilizes both the essentializing tendencies of conventional syntax, and the "coherence imperative" nested in the logical law of non-contradiction. Indeed, the "is of identity" and the definite article "the" assign an essence to an entity, an essence that we tend to treat as permanent and stable. "Either/or" are logical operators that reinforce this identity, as an entity cannot be both A and non-A: you are either male or female. The contestation of this "law of identity" inherited from classical logic appears under various guises during the $20^{\text {th }}$ century, notably through developments in quantum physics and thought experiments such as "Schrödinger's cat" in which material states are undecidable. It is also central to A. E. van Vogt's novel's The World of Null-A (1948), which was inspired by Korzybski's elaborations on "non-Aristotelician logic." Interestingly, Korzybski also evokes the viral nature of the "language of identity":

Identification appears also as something 'infectious,' for it is transmitted directly or indirectly from parents and teachers to the child by the mechanism and structure of language, by established and inherited 'habits of thought,' by rules for life-orientation, etc. (1994: xci)

Burroughs follows Korzybski's denunciation of the infectious grammar of identity when he designs novelistic spaces where ontology is fluid and metamorphosis reigns. Naked Lunch, 
The Nova Trilogy, and The Wild Boys provide the reader with a psychedelic drug against the viral constraints of enforced individual identities. By allowing the reader to become an eelboy or a mutant erotic tree in a non-linear narrative, The Wild Boys destabilizes simultaneously the linear logic of language and story, and the biopolitical and anatomopolitical (Foucault 2012) constraints on our bodies (such as the imperatives of reproductive, monogamous heterosexuality, that imply a normative "life syntax").

\section{The cut-up: a tactical move against viral agents of mind control}

In Burroughs' novels, the association lines through which mass media and language exert their control are attacked by various strategies. One of these strategies is the cut-up technique used in the Nova Trilogy, where Burroughs would cut a page in four, and rearrange it to create new associations. This rearrangement generates or accompanies numerous repetitions and variations of images and passages. Through these variations, things are rarely assigned permanent condition: characters are never quite definite, they inhabit spaces that are both past AND present, both mythical AND realist; episodes are not cause OR consequence, they are cause AND consequence, and so on. Thus, Burroughs' writing embraces contradiction and simultaneity, refusing the coherence imperative and laws of non-contradiction that are the backbone, as Barthes (1975: 3) argues, of so many of our legal and social institutions: court, school, polite conversation... but also gender, professional identity, and so on.

Across the Nova Trilogy, Naked Lunch and the Wild Boys, phrases and scenes are repeated, reappearing in rearranged form, disrupting the mere possibility of narrative progression, of a linear narrative efficiently oriented toward resolution. For example, let us have a look at the following passage of The Soft Machine - a call sent by Uranian Willy the Heavy Metal Kid to 
resist and attack the ready-made sentences and fixed images disseminated by the evil Nova Mob, an alien force of mind and social control:

Photo falling - Word falling - Use partisans of all nations - Target Orgasm Ray Installations - Gothenburg Sweden - Coordinates 8276 - Take studio - Take board Books - Take Death Dwarfs - Towers open fire.

Calling partisans of all nations - Shift linguals - Cut word lines - vibrate tourists - Free doorways - Photo falling - Word falling - Break through in grey room. (1967: 156)

The key action here is "cut": the action that disconnects, that stops the efficacy of control formulas, stops the machine, stops the film ("Photo falling - Word falling"). We can see here that such cutting is operated not only on narrative sequences, but also on syntactical units, disjointed by dashes creating a syncopated rhythm. But larger elements, such as images, scenes or narrative conceits, are also cut-up, displaced and re-contextualized. This is what happens with the passage above, re-used three years later in Nova Express, in a slightly different context, since the call for revolt is now "heard" from the point of view of a technician working for the Nova Mob:

The Technician mixed a bicarbonate of soda surveying the havoc on his view screen [...] - Personnel decimated - Board Books destroyed - Electric waves of resistance sweeping through mind screens of the earth - The message of Total Resistance on short wave of the world - This is war to extermination - Shift linguals - Cut word lines Vibrate tourists - Free doorways - Photo falling - Word falling - Break through in Grey Room - Calling Partisans of all nations - Towers, open fire - (1965: 63) As Noëlle Batt (1976) demonstrates, syntagmatic rupture and contextual displacement reorder the temporality of the reader's experience: as she encounters a sentence met previously, she is projected in the past, while she knows she might read it again in the future. The reader's temporal consciousness is thus disorientated, and freed from linearity and straightforward 
succession and causality.

The repetition of a limited number of similar images, often surreal and erotic, disrupts narrative progression, while intensifying these images. Thus freed from the chains of narrative syntax, they become alive, materially dense, physically present through embodied interpretation, resonating in the reader's brain, muscles, viscera and loins, replacing the viral structures of logical thought and stereotypical narrative sequences by psychedelic images, acting like drugs able to "clean the doors of perception" (to use Wordsworth's phrase after Aldous Huxley and Jim Morrison). The last pages of the chapter entitled "The Wild Boys" represent explicitly the breaking down of a fluid narrative scene into discrete images, the passage from the "film of reality" to an evocative and syncopated "story book." The scene, in which the wild boys fallen in combat are given the possibility to be reborn through homoerotic shamanic reproduction (aligned with Donna Haraway's (1991) vision of cyborg reproduction), is also useful to think about the Burroughs' refusal of the normative "life syntax" (grow up, marry, have children...):

The boys create offspring known as Zimbus. [...] Zimbus are created after a battle when the forces of evil are in retreat... (1971: 155)

A boy with Mongoloid features steps onto the rug playing a flute to the four directions. As he plays a phantom figures swirl around him taking shape out of the moonlight, campfires and shadows. He kneels in the center of the rug playing his flute faster and faster. The shape of a boy on hands and knees is forming in front of him. He puts down his flute. His hands molds and knead the body in front of him pulling it against him with stroking movements that penetrate the pearly grey shape caressing it inside. The body shudders and quivers against him as he forms the buttocks around his penis stroking silver genitals out of the moonlight grey then pink and finally red the mouth parted in a 
gasp shuddering genitals out of the moon's haze a pale blond boy spurting thighs and buttocks and young skin. [...] The Zimbus sleep in the blue tent. Picture in an old book with gilt edges. The picture is framed with roses intertwined . . two bodies stuck together pale wraith of a blond boy lips parted full moon a circle of boys in silver helmets naked knees up. Under the picture in gold letters. Birth of a Zimbu. Boy with a flute charming a body out of the air. I turn the page. Boy with Mongoloid features is standing on a circular rug. [...] I turn the page. A boy is dancing will-o'-the-wisp dodges in front of him. I turn the page. (1971: 160-161)

Here, narrative progression is disrupted by the repetition of the scene in reversed-ekphrasis (as the diegetic scene becomes a series of images in a book with "gilt edges" and "gold letters," signs of nostalgia and materiality in The Wild Boys). Abstracted from their context, these images gain autonomy and intensity. Eventually, they will themselves fall victim to disconnection, but on the level of the sentence, as the last image of the chapter is itself an agrammatical sentence made of recurring elements in the novel ("Dawn short framed in roses dawn wind between his legs distant lips").

In The Wild Boys, just like images are freed from the logical chains of narrative, desire and eroticism are freed from the biopolitical logic of monogamous heterosexual reproduction, a logic that might be traced back to the language virus. This link between reproductive and linguistic politics is articulated in The Electronic Revolution:

I have frequently spoken of word and image as viruses or as acting as viruses, and this is not an allegorical comparison. It will be seen that the falsifications of syllabic Western languages are in point of fact actual virus mechanisms. The IS of identity; the purpose of a virus is to SURVIVE. To survive at any expense to the host invaded. To be an animal, to be a body. To be an animal body that the virus can invade. To be animals, 
to be bodies. To be more animal bodies, so that the virus can move from one body to another. (2005: 35)

The essentialist assignation of identity through logical syntactical units based on the "IS of identity" is here presented as being part of the biopolitical rule of the virus, where reproductive norms are imposed through repetitive discourse and narrative. But contrarily to Foucault, that ascribes the biopolitical imperative of heterosexual reproduction to nationalcapitalist projects of turning the social body into a competitive productive machine (2012: 14), for Burroughs, it is the non-human, viral agency of the language-virus that presses for the proliferation of humans. Against this systemic, non-human agency, and as we have just seen, he creates homo-social communities and modes of reproduction founded on cyclical reincarnation, thus disobeying the demands for production and growth typical of competing industrial societies. The wild boys are not workers, but fighters, roasting their enemies for sustenance and living in nomadic networks that oppose the forces of modernheteronormative-liberal-industrial/agricultural capitalism. Burroughs" claim that "word and image acting as viruses [facilitating the proliferation of bodies] is not an allegorical comparison" might appear far-fetched. But we will now see that similar ideas on virality and code circulate within various scientific circles.

\section{The language virus beyond Burroughs}

One of the most famous iteration of the "agency of code" idea is articulated by anthropologist Terrence Deacon in The Symbolic Species, his work on the co-evolution of language and brain:

Of course, languages are entirely dependent on humans, and are not separate physical organisms, replete with their own metabolic processes and reproductive systems. And yet their very different form obscures deep similarities to living processes. They might 
better be compared to viruses. Viruses are not quite alive, and yet are intimately part of the web of living processes. [...] They are minimally packaged strings of DNA or RNA that regularly happen to get themselves insinuated into cells that mistake them for their own nucleotides and haphazardly replicate them and transcribe their base sequence into proteins. [...]. Languages are inanimate artifacts, patterns of sounds and scribblings on clay or paper, that happen to get insinuated into the activities of human brains which replicate their parts, assemble them into systems, and pass them on. (1998: 112)

Just like in Burroughs' mythos, here the "language virus," passed from generation to generation, is located within a human evolutionary history, as it forms a symbiotic relation with its host. Deacon then goes on to compare our relation with language with the one we have with our intestinal microbiome, as in both case, the partners (humans-language / humans-gut microbes) could not survive without each other, both needing cohabitation to flourish, to co-evolve and co-adapt. But the language/virus parallel is not only made on the grounds of their shared ability to form symbiosis. As Deacon mentions here, language and viruses are both semiotic entities. Indeed, viruses are "strings of DNA or RNA." And as the Puppet Master, a consciousness born from the sea of global information networks, says in Ghost in the Shell (Oshii 1995): "It can also be argued that DNA is nothing more than a program designed to preserve itself."

I mention Oshii's anime to show that Burroughs' campaign against the language virus is part of a broader history surrounding the idea that code possesses autonomy, a destiny, and maybe even an agency (especially linguistic, genetic, and digital codes). Notably popularized by Richard Dawkins' controversial book The Selfish Gene (1976), the idea that the genetic code uses individual humans to perpetuate itself echoes with Burroughs myth of the language virus, 
extending it within the scientific domain. The validity of the science notwithstanding, Oshii's masterpiece shows that the posthumanist (in the sense of Hayles 1999) perspective can lead to fertile artistic propositions: Burroughs writing against the viral biopower of language opens toward a reconsideration of the role we assign to literature in relation to ecology and to life processes. Such reconsideration is also demanded by the striking (albeit relative) similarity in the cut-up strategy used by Burroughs and in that of certain bacteria in their fight against viruses.

\section{CRISPR/Cas9: cutting the virus, reprogramming the code}

Indeed, bacteria such as Streptococcus pyogenes are able to cleave the genomic sequence of invading viruses (bacteriophages, or just "phages") with their "scissors," the Cas9 nuclease enzyme (Heler et al 2015). This strategy is considered an adaptive immunity, as the bacteria, when infected by a phage virus, can copy parts of the viral genomic sequence and integrate them inside its own DNA, interspacing these foreign sequences (called "spacers") between redundant parts of its own DNA (called "CRISPR repeats" or "Clustered Regularly Interspaced Short Palindromic Repeats," discovered by the team of Yoshizumi Ishino in 1987). This integration of copied spacers leads to a co-evolution of the host and viral genomes, allowing the next generations of bacteria, when they encounter the virus, to efficiently identify it, generating RNA molecules that will guide Cas9 to target the viral DNA sequences originally copied, to splice them and in so doing incapacitate the attacking bacteriophage (Yin 2012). Burroughs uses a similar strategy: his texts use the written word (the virus) against itself, cutting its stereotypical sequences (syntax, narrative) to disable it. 
According to the classical model of molecular biology, established by Crick and Watson's double-helix model in the 1950s, the physical gene is "a linearly organized set of instructions that gave rise to phenotypic expression" (Charbel et al 2009: 34). Although Charbel, Queiroz and Emmeche criticize this quasi-mechanist vision of gene functioning, we see that linearity appears as a central quality of the genome. In CRISPR-Cas9, it is the structural quality of linearity or "sequentiality" that allows the bacteria to disable the invading virus, as its "lines of genetic code" can be copied, pasted, and materially cut up. These operations on linear structures are strikingly similar to Burroughs' cut-ups that cleave the sequences of the language virus, the lines of association created by discursive norms. Just like in a literary text, the "meaning" of a genetic sequence changes with the order of its genes. This was known as early as 1925, when Sturtevant discovered the "position effect" according to which the position of a gene in the chromosome can change its effect on the phenotype (Charbel et al 2009: 30). Thus, the determining factor in the genetic shaping of living matter is not only the material specificities of a particular gene sequence, such as their quantity for example, but the relations and combinations happening within a complex biological system: "Both many-toone and one-to-many relationships between DNA sequences and RNA/polypeptide sequences give support to a picture of molecular complexity in which the amount of genes is not the crucial feature, but rather complex information networks, such as those meditated by transcription factors, and intricate patterns of gene expression which allow of a huge diversity of proteins and RNAs based in a limited number of genes. (Charbel 2009: 49). The same logic applies to language, where a "huge diversity of meanings is based on a limited number of signifiers." As a consequence, the cutting up and recombination of code sequences is a powerful way of producing new meanings, and of proposing alternatives to stereotypical narratives "programmed" to help the proliferation of humans and their language virus. 
But the parallels between CRISPR-Cas9 and Burroughs textual guerilla do not stop at the cutup. Notice that the bacteria first "copies" parts of the invading DNA, that it then integrates between "Palindromic Repeats" present in its own genome. In a sense, Burroughs' writing operates in a similar manner, insofar as it works by decontextualizing syntactical units (copying them out) from their original locus (normal language), and re-contextualizing them within his text, which is frequently redundant (if not palindromic, although it would be interesting to seek palindromic structures at various levels of his works). Even though the redundancy and non-linearity of Burroughs' novels from Naked Lunch to The Wild Boys might not be properly palindromic, it allows them to use a form of resistance to the stereotypical syntactical associations of the language virus, a form of adaptive immunity akin to CRISPR-Cas9 in the sense that both are integrative cut-up strategies. The similarity in the techniques used by bacteria and by Burroughs to fight against viral forces might appear coincidental (and probably is), but still it reveals the centrality of code both in the development of our civilization and in that of living forms. In this sense, Burroughs was right in identifying writing (a coding practice) as a biological, viral force.

\section{Concluding with The Wild Boys - A Book of the Dead}

By cutting up the language virus, Burroughs' images and narrative are freed from the imperatives of efficiency, resolution and reproduction. Instead, they offer queer forms of vitality and desire:

In jade aquariums human rectums and genitals grafted onto other flesh... a prostate gland quivers rainbow colors through a pink mollusks... two translucent white salamanders squirm in slow sodomy golden eyes glinting enigmatic lust... (1971: 20-22) 
Burroughs' mutant life forms are not fit for reproductive growth. On the contrary, they offer pleasures that are often deadly, like a pharmakon able to cure the over-efficacy imposed by the viral forces of code that has led humans to proliferate, in overflowing, ecologically threatening reproductive vitality. By inhabiting his novels, the reader is caught in singular assemblages where the vegetal, the animal and the technological collide, where fluid genders abound, where media and pharmacology open up hybrid possibilities of living and feeling, and where things are never assigned a definite, exclusive identity. This experience of metamorphosis and narrative circularity counteract the language virus, opening toward less systemic forms of communication, toward semiotic techniques that are more idiosyncratic and local, such as the one used by the wild boys:

Exchange of spells and potions. A common language based on variable transliteration of a simple hieroglyphic script is spoken and written by the wild boys. In remote dream rest areas the boys fashion these glyphs from wood, metal, stone and pottery. [...] These words objects travel on the trade routes from hand to hand. The wild boys see, touch, taste, smell the words. (1971: 151)

Just like Burroughs writing gives us a sensual experience of language, words used by the wild boys are fashioned in a slow, "arts and craft" manner that disrupts the acceleration of global communication and capitalism. Against efficiency and growth, stability and linearity, Burroughs cuts global language and networks with arts and craft and sensual signs, signs forming ekphrastic images that can be entered, touched and smelled. The abstract code, systemic and syntactical, is replaced by concrete word-objects, felt experiences that are not conventional and interchangeable, but sensual and always singular. By doing just that in its own writing, Burroughs situates literature in the biosemiotic realm, where signs are connected with the physiological. This reconnection of literature and biology is charged with political, economical and ecological potential. By overthrowing the language virus and its demands for 
efficacy, production and reproduction, The Wild Boys dreams of overthrowing the colonial world order, allowing Western Europe and North America to be saved through the destruction of its "coded" civilization by hordes of erotic wild boys from Africa and South and Central America (1971: 138). Even though the world has changed much since the control-obsessed 1950s and 1960s, Burroughs' visions, in their celebration of nomadism, erotic hybridity and queer materiality, can still act as a powerful antibody for the virus of ready-made thought and narrow-mindedness, a biosemiotic cure much needed at a time when humanity has to question its own habits and proliferation.

\section{References}

BARDINI, T. (2006) “Hypervirus: A Clinical Report,” ctheory.net, (https://journals.uvic.ca/index.php/ctheory/article/view/14470/5312), online [April 17 ${ }^{\text {th }}, 2017$ ].

BARDINI, T. (2011) Junkware. Minneapolis: University of Minnesota Press, Posthumanities series.

BARDINI, T. (2014) "The Strange Filiations of the Stranger Count: Korzybski and Cyberculture" Paper presented at the NCA 94th Annual Convention, San Diego, CA.

BAPTESTE, E. (2017) "Contribution of symbiogenetic genes to evolutionary transitions" Paper presented at the conference "Symbiosis in Evolution, Biology and Human Health, Paris.

BARTHES, R. (1975) The Pleasure of the Text. New York: Farrar, Straus and Giroux. 
BATT, N. (1976) “Rupture et déplacement dans l'œuvre de William Burroughs” In Revue Française d'Études Américaines 1: 11-21.

BATT, N. (1977) “Bitextualité dans l'oeuvre de William Burroughs” In Trema 2 (Fictions Américaines Contemporaines): 59-70.

BATT, N. (1992) “William Burroughs, entre Censure et Césure” In Cycnos 9 (La censure aux Etats-Unis): 35-39.

BEL ENGUIX, G. and M. D. JIMENEZ-LOPEZ (2012) "Natural Language and the Genetic Code: From the Semiotic Analogy to Biolinguistics" In Proceedings of the 10th World Congress of the IASS.

BOULENGER V., O. HAUK and F. PULVERMÜLLER (2009) "Grasping Ideas with the Motor System: Semantic Somatotopy in Idiom Comprehension" In Cerebral Cortex 19: 19051014.

BRUCKER R. M. and S. R. BORDENSTEIN (2012) "Speciation by symbiosis" In Trends in Ecology \& Evolution 27 (8): 443-451.

BURROUGHS, W. S. (1967 [1961]) The Soft Machine. Evergreen Black Cat Edition. New York: Grove Press.

BURROUGHS, W. S. (1965 [1964]) Nova Express, Evergreen Black Cat Edition, New York, 
Grove Press, p. 155-156.

BURROUGHS, W. S. (2005 [1970]) The Electronic Revolution. Ubu Classics online, http://www.ubu.com/historical/burroughs/electronic_revolution.pdf, accessed April 19, 2017.

BURROUGHS, W. S. (1971) The Wild Boys: A Book of the Dead. New York: Grove Press.

BURROUGHS, W. S. and D. ODIER (1979 [1969]) Le Job. Entretiens avec Daniel Odier. Paris: Belfond.

CHARBEL, N. E., J. QUIEROZ \& C. EMMECHE. (2009) Genes, Information, and Semiosis. Tartu: Tartu Semiotics Library.

CHARPENTIER, E. (2016) « 2 minutes pour comprendre le CRISPR-Cas9 », ARTE.tv, [http://sites.arte.tv/28minutes/fr/le-crispr-cas9-28minutes], consulté le 21 juin 2017.

DAWKINS, R. (1976) The Selfish Gene. Oxford: Oxford University Press.

DEACON, T. W. (1998) The Symbolic Species: The Co-evolution of Language and the Brain. New York: W. W. Norton \& Company.

DELEUZE, G. (1992) "Postscript on the Societies of Control” In October (59): 3-7.

DUNNE, M. W. (2013) A Cold War State of Mind-Brainwashing and Postwar American Society. Amherst: University of Massachusetts Press. 
CHARBEL, E. N., J. QUEIROZ and C. EMMECHE (2009) Genes, Information, and Semiosis. Tartu: Tartu University Press, Tartu Semiotics Library series.

FISETTE, J. (1996) Pour une pragmatique de la signification. Montréal: XYZ.

FOUCAULT, M. (2012 [1976]) "The Mesh of Power" In Viewpoint Magazine. Online, accessed February 24, 2016.

GALLESE V. and G. LAKOFF (2005) "The Brain's Concepts: the Role of the Sensory-Motor System in Conceptual Knowledge" In Cognitive Neuropsychology 22 (34): 455-479.

HARAWAY, D. (1991) "A Cyborg Manifesto: Science, Technology and Socialist-Feminism in the Late Twentieth Century" In Simians, Cyborgs and Women: The Reinvention of Nature. New York: Routledge, 149-181.

HAYLES, N. K. (1999) How We Became Posthuman: Virtual Bodies in Cybernetics, Literature, and Informatics. Chicago: University of Chicago Press.

HELER S., P. SAMAI, J. W. MODELL, C. WEINER, G. W. GOLDBERG, D. BIKARD \& L. A. MARRAFINI (2015) “Cas9 Specifies Functional Viral Targets During CRISPR-Cas Adaptation” In Nature 519: 199-202.

ISHINO Y., H. SHINAGAWA, K. MAKINO, M. AMEMURA and A. NAKATA (1987)

"Nucleotide Sequence of the iap Gene, Responsible for Alkaline Phosphatase Isozyme 
Conversion in Escharichia coli, and Identification of the Gene Product" In Journal of Bacteriology 169 (12): 5429-5433.

JAKOBSON, R. 1973. Essais de linguistique générale. 2. Rapports internes et externes du langage. Paris, Minuit.

KONSTANTINOU, L. (2014) “The Eccentric Polish count Who Influenced Classic SF’s Greatest Writers" In i09. Online (http://io9.gizmodo.com/the-eccentric-polish-count-whoinfluenced-classic-sfs-g-1631001935), accessed April 17, 2017.

KORZYBSKI, A. (1921) Manhood of Humanity; The Art and Science of Human Engineering. New York: E. P. Dutton \& Company.

KORZYBSKI, A. 1994 [1933], Science and Sanity. An Introduction to Non-Aristotelician Systems and General Semantics. New York: Institute of General Semantics.

KORZYBSKI, A. (1939) Five Lectures on General Semantics, Alfred Korzybski Literary Estate, archive.org. Online, accessed May 12, 2017.

LOTMAN, J. [1971/1977]. The Structure of the Artistic Text. Ann Arbor: University of Michigan Press.

LYDENBERG, R. (1987) Word Cultures: Radical Theory and Practice in William S. Burroughs' Fiction. Champaign: University of Illinois Press. 
MARGULIS, L. (1976) “Genetic and Evolutionary Consequences of Symbiosis” In Experimental Parasitology 39 (2): 277-349.

OSHII, M. (1995) Ghost in the Shell. Los Angeles: Manga Entertainment.

ROSENBERG, E. and I. ZILBER-ROSENBERG (2014) The Hologenome Concept: Human, Animal and Plant Microbiota. Berlin: Springer Science.

YIN, S. (2012) “What Is CRISPR/Cas9 and Why Is It Suddenly Everywhere?” In Motherboard/Vice Magazine. Online, accessed June 6, 2017.

\section{Biography}

Assistant professor of American literature at Sorbonne-Nouvelle University (Paris III), PierreLouis Patoine is the author of a book on the role of the empathic, physiological body in the experience of reading (Corps/texte, ENS Editions, 2015). He has published articles on contemporary American literature, biosemiotics and literary neuroaesthetics, is co-editor of the online journal Epistemocritique (http://epistemocritique.org) and co-director of the Science/Literature research group (hypotheses.litorg.org). 